\title{
ANALISIS KANDUNGAN GIZI EKSTRAK KULIT SALAK PRODUKSI KELOMPOK TANI ABIAN SALAK DESA SIBETAN SEBAGAI UPAYA PENGEMBANGAN POTENSI PRODUK PANGAN LOKAL
}

\author{
I Gusti Ayu Sri Dhyanaputri ${ }^{1}$, I Wayan Karta ${ }^{2}$, Luh Ade Wilan Krisna ${ }^{3}$
}

\begin{abstract}
Background Snakefruit more technically known as 'Salak' (Salacca sp) is native fruit of Indonesia regarded as exotic fruit that can consumed not only its flesh fruit but also its skin in the form of extract as it has an efficacy. Extract of snakefruit rind can be proceed into a healthy beverages that contains phenolic compounds which known as natural antioxidants.

Objective This study aimed to describe the content of nutrients such as carbohydrates, proteins, and antioxidants in the extract of snakefruit rind products.

Methods This research is a descriptive study that examines the content of carbohydrates, protein, and antioxidants in the extract of snakefruit rind products. Samples were rind of snakefruit with various concentration masses, in water ratio 1\%, 5\%, 10\%, and non compositions.

Result Carbohydrate, protein, antioxidant capacity and IC50 respectively for each composition, are (1) the composition of the 1\%: -0.04\%; 0.21\%; $20.70 \mathrm{ppm}, 426.58 \mathrm{ppm}$; (2) the composition of 5\%: 0.82\%; 0.20\%; $73.40 \mathrm{ppm} ; 151.41 \mathrm{ppm} ;(3)$ the composition of 10\%: $0.93 \%$; 0.20\%; 110.29 ppm; 87.11 ppm; (4) non composition: $28.14 \%$; 44.90\%; 215.10 ppm; $56.10 \mathrm{ppm}$, and non composition: $1.00 \%$; 0.00\%; $25.73 \mathrm{ppm} ; 92.18 \mathrm{ppm}$.

The most potential nutrient compound in extract of snakefruit rind is the antioxidant, which produced as beverages like tea product. The composition of $10 \%$ is the most active category of antioxidant activity

Conclusions This study revealed that extract of snakefruit rind can produced as healthy beverages (such as tea), as it is a potential wastes treatment for local food products. The extract of snakefruit rind consist of nutrition just like proteins, carbohydrates which are great for health and also contains lots of a powerful antioxidant.
\end{abstract}

Keywords: Rind of snakefruit. Antioxidant, Tea

\section{PENDAHULUAN}

Pengolahan buah salak menjadi berbagai macam produk tentunya memberikan nilai ekonomis terhadap buah salak. Pengolahan buah salak ini tentunya juga menghasilkan sampah berupa kulit salak. Kulit salak ini kemudian diolah oleh masyarakat dengan cara mengekstrak kulit salak menjadi minuman.

1.,2.,3., Jurusan Analis Kesehatan Poltekkes Denpasar Korespondensi : I Gusti Ayu Sri Dhyanaputri ${ }^{1}$, Jurusan Analis Kesehatan, Poltekes Denpasar, Jalan Sanitasi No. 1 Sidakarya, Denpasar-Bali 80224, Indonesia.

Telp. +62-361-710 527, Fax. +62-361-710 448

Email : meditoryjournal@gmail.com 
Ekstrak ini diharapkan memiliki kandungan gizi yang berguna bagi kesehatan masyarakat. Namun hasil ekstrak kulit salak belum diketahui kandungan gizinya seperti karbohidrat, protein, dan antioksidan yang bermanfaat untuk kesehatan.

Berdasarkan beberapa hasil penelitian, salak memiliki kandungan gizi yang baik untuk kesehatan. Salak memiliki kandungan karbohidrat yang tinggi, vitamin C, kalsium, fosfor, zat besi, serta antioksidan. Buah salak jenis Bongkok memiliki aktivitas antioksidan dan antihiperurikemia yang diekstrak dengan etil asetat $^{1}$. Salak Bali dan salak Nglumut memiliki kadar komponen bioaktif (vitamin $\mathrm{C}$ dan senyawa fenolik) dan aktivitas penangkapan radikal DPPH (2,2diphenyl-1-picrylhydrazil) yang tidak berbeda nyata namun secara signifikan lebih tinggi daripada salak Pondoh ${ }^{2}$. Selain buah salak, kulit salak juga banyak diteliti memiliki antioksidan. Hasil uji fitokimia menunjukkan kulit buah salak mengandung senyawa flavonoid dan tannin serta sedikit alkaloid. Kandungan flavonoid di dalam ekstrak kulit salak mampu menurunkan kadar glukosa dalam darah $^{3}$. Ekstrak etanol kulit buah salak mengandung metabolit sekunder alkaloid, polifenolat, flavonoid, tanin, kuinon, monoterpen dan seskuiterpen. Ekstrak etanol kulit buah salak memiliki aktivitas antioksidan dengan nilai IC50 sebesar $229,27 \pm 6,35(\mu \mathrm{g} / \mathrm{mL})^{4}$. Kandungan gizi ini tentunya akan mengalami perubahan dalam proses pengolahannya. Penelitian mengenai analisis kandungan gizi pada ekstrak kulit salak yang diproduksi oleh kelompok tani Abian Salak di Desa Sibetan, Karangasem perlu dilakukan, untuk memberikan informasi bahan pangan bermutu dari suatu
pengolahan.Data kandungan gizi ini nantinya dapat bermanfaat sebagai bahan informasi kandungan gizi kepada masyarakat sebagai potensi produk pangan lokal, bagi kelompok tani atas produk yang dihasilkan, serta sebagai penelitian lanjutan mengenai produk olahan salak bagi kesehatan.

\section{METODE}

Penelitian ini merupakan jenis penelitian deskriptif yang mengkaji kandungan karbohidrat, protein, dan antioksidan pada produk ekstrak kulit salak. Sampel yang akan dianalisis adalah sampel kulit salak, ekstrak kulit salak dengan variasi konsentrasi perbandingan massa kulit salak dengan air yaitu 1\%, 5\%, dan $0 \%$, dan non komposisi.

Uji kandungan karbohidrat menggunakan metode perhitungan kasar (proximat analysis) atau disebut juga Carbohydrate by Difference, kandungan protein dengan Semi mikro Kjeldahl, serta analisa antioksidan dan aktivitasnya dengan Spektrofotometer menggunakan $\mathrm{DPPH}^{5}$.

Data yang telah diperoleh dari hasil pemeriksaan laboratorium diolah secara manual dan dianalisis secara deskriptif dalam bentuk tabel ataupun grafik, dan narasi dengan kajian pustaka yang relevan.

\section{HASIL DAN PEMBAHASAN}

\section{Hasil}

Hasil kegiatan penelitian ini adalah rebusan kulit salak dan kadar proksimat serta aktioksidannya. Setiap komposisi campuran antara kulit salak dengan air yaitu $1 \%, 5 \%$, dan $10 \%$ (jumlah air yang digunakan yaitu $200 \mathrm{~mL}$ atau setara dengan 1 gelas air). Setelah dilakukan pengujian di laboratorium 
dihasilkan data sebagai berikut seperti Tabel 1 .
$10 \%$, agar dalam pengembangan produknya komposisi penambahan kulit salak dalam air tidak terlalu banyak, namun tetap diperoleh

Tabel 1. Hasil Analisis Kandungan Gizi Ekstrak Kulit Salak pada Variasi Komposisi

\begin{tabular}{ccccccc}
\hline \multirow{2}{*}{ Sampel } & $\begin{array}{c}\text { Kapasitas } \\
\text { antioksidan }\end{array}$ & IC 50\% & Air & Abu & Protein & Karbohirat \\
\cline { 2 - 7 } & $\begin{array}{c}\text { ppm } \\
\text { GAEAC }\end{array}$ & ppm & $\%$ bb & $\%$ bb & $\%$ bb & $\%$ bb \\
\hline $\begin{array}{c}\text { Kulit } \\
\text { salak }\end{array}$ & 215,10 & 56,10 & 13,71 & 8,40 & 44,90 & 28,14 \\
\hline $1 \%$ & 20,70 & 426,58 & 99,69 & 0,13 & 0,21 & $-0,04$ \\
\hline $5 \%$ & 73,40 & 151,41 & 98,65 & 0,30 & 0,20 & 0,82 \\
\hline $10 \%$ & 110,29 & 87,11 & 98,37 & 0,47 & 0,20 & 0,93 \\
\hline $\begin{array}{c}\text { non } \\
\text { komposisi }\end{array}$ & 25,73 & 192,18 & 99,57 & 0,15 & 0,00 & 0,01 \\
\hline
\end{tabular}

\section{Pembahasan}

Berdasarkan hasil pengujian seperti Tabel 1, terjadi perubahan dari kulit salak kemudian diolah menjadi ekstrak kulit salak dan dikenal sebagai teh kulit salak. Tingkat kekuatan antioksidan pada kulit salak tergolong aktif karena berada pada rentangan 50-100 ppm. Komposisi campuran yang memiliki tingkat kekuatan antioksidan aktif yaitu komposisi 10\%, sedangkan komposisi 5\% dan non komposisi memiliki tingkat kekuatan antioksidan sedang, sedangkan komposisi $1 \%$ memiliki tingkat kekuatan antioksidan lemah. Jika dilihat pada setiap komposisi, diperoleh pola bahwa semakin ditingkatkan komposisi campurannya, maka kadar antioksidanya juga semakin tinggi. Hal ini tentu berhubungan dengan semakin banyak kulit salak yang ditambahkan, maka semakin banyak zat antioksidan akan larut dalam campuran. Komposisi dibatasi sampai manfaat antioksidannya. Variasi komposisi $10 \%$, memberikan nilai kekuatan antioksidan yang aktif. Tabel 1, menunjukkan kandungan karbohidrat, protein, dan kadar abu tidak memberikan nilai tambah pada produk. Hal ini karena kadarnya sangat rendah, sehingga yang lebih banyak nanti dimanfaatkan dalam produk ini adalah antioksidannya. Rendahnya kandungan tersebut dibandingkan dengan kulit salaknya karena terdapat proses pelarutan dengan air dan terjadi proses pengenceran. Hal ini dapat kita perhatikan, semakin tinggi komposisi campuran kandungan karbohidrat semakin tinggi, sedangkan pada protein banyak terdapat perbedaan yang disebabkan oleh karena berhubungan dengan protein terlarut.

Pada proses pembuatan ekstrak ini terdapat perbedaan antara hasil pada antioksidan kulit salak dengan variasi komposisi. Hal ini berarti tidak semua 
antioksidan yang terdapat dalam kulit salak dapat larut dalam air. Antioksidan berdasarkan kelarutannya dapat dibedakan menjadi antioksidan yang larut dalam air (hidrofilik) dan yang larut dalam lemak (hidropobik). Secara umum antioksidan yang larut dalam air bereaksi dengan oksidan di sitoplasma sel dan plasma darah. Sedangkan antioksidan larut lemak melindungi membran sel dari peroksidasi lemak ${ }^{6}$. Oleh karena itu, dalam ekstrak kulit teh kulit salak yang diperoleh adalah antioksidan yang larut dalam air dan perlu dilakukan penelitian lebih lanjut mengenai jenis antioksidan yang terdapat pada ekstrak kulit salak, seperti antioksidan jenis polifenol yang lebih larut dalam air. Berdasar nilai kapasitas antioksidan dan IC50, ekstrak kulit salak memiliki potensi besar untuk dipasarkan menjadi produk pangan lokal sebagai minuman berantioksidan khas Karangasem dan berguna untuk kesehatan, selain itu juga sebagai upaya pemanfaatan kulit salak sehingga bernilai ekonomis. Bentuk produk ini dapat berupa celup bubuk kulit salak yang telah dikeringkan dan dikemas. Produk ini akan dikenal sebagai teh kulit salak. Istilah "Teh" memiliki makna yang cukup luas, tidak hanya berlaku untuk sebutan tanaman Camellia sinensis (pohon teh). Semua jenis minuman dari tanaman apapun yang disajikan dengan cara diseduh bisa disebut sebagai "Teh". Berbagai jenis minuman yang dihasilkan dari daun, kulit, akar, bunga tumbuhan lain selain tanaman teh juga disebut dengan istilah teh. Misalnya adalah teh ginseng, teh bunga melati, teh daun sirsak, teh bunga rosela atau teh krisan ${ }^{7}$.Teh kulit salak sangat bermanfaat untuk kesehatan karena antioksidan dewasa ini semakin diperlukan oleh masyarakat dalam menjaga kesehatannya dari proses oksidasi dan radikal bebas.

Antioksidan bersifat meredam atau menetralkan radikal bebas dan senyawa oksigen reaktif. Antioksidan dengan mencegah kerusakan oksidatif oleh pengaruh oksidan terhadap target (DNA, RNA, protein dan lipida), akan bersifat protektif pada individu yang tidak memiliki sel kanker ${ }^{8}$. Antioksidan yang kemungkinan banyak larut dalam ekstraks kulit salak adalah senyawa polifenol. Hal ini didukung oleh adanya kandungan polifenol yang sangat tinggi pada jenis salak pondoh, nglumut, dan $\mathrm{Bali}^{2}$. Jenis polifenol ini dapat berupa flavonoid. Flavonoid merupakan senyawa polifenol yang dikenal memiliki aktivitas antikanker. Sedikitnya terdapat 5 mekanisme aktivitas antikanker dari polifenol. Pertama, kemampuan antioksidan dari polifenol dapat melindungi sel dari kerusakan DNA dengan membersihkan sel dari radikal bebas (Reactive Oxygen Species / ROS). Kedua, polifenol memodulasi protein yang berperan dalam jalur transduksi signal seperti activator protein 1 (AP-1), mitogen-activated protein kinase (MAPK), phosphatidylinositol 3-kinase (PI 3'-K), p70S6-K dan Akt. Ketiga, polifenol mengurangi aktivitas dari tyrosine kinase receptors (PDGF-R $\beta$, EGF-R) yang berperan dalam proliferasi ganas dari sel tumor. Keempat, polifenol menginduksi apoptosis pada sel tumor. Kelima, polifenol mengatasi resistensi multiobat dengan memblok efluks P-glycoprotein (P-gp) terhadap obat-obat antikanker. Kelima mekanisme tersebut yang berperan dalam mekanisme sitotoksik adalah dengan menginduksi program kematian sel (apoptosis) ${ }^{9}$. 
Menurut penelitian sebelumnya, mekanisme apoptosis dari senyawa polifenol tanaman adalah dengan mobilisasi tembaga (copper) intraselular dan ekstraselular. Senyawa-senyawa polifenol seperti flavonoid, tannic acid, gallic acid, curcumin, dan resveratrol menyebabkan pemecahan rantai oksidatif di dalam DNA dengan adanya $\mathrm{Cu}$ (II). Pada reaksi ini, $\mathrm{Cu}$ (II) direduksi menjadi $\mathrm{Cu}$ (I), dan Reactive Oxygen Species (ROS) seperti hydroxyl radical $(\mathrm{OH} \bullet)$ terbentuk, yang berperan sebagai agen pemecah DNA ${ }^{10}$. Mekanisme lain dari flavonoid dalam menginduksi apoptosis sudah banyak diteliti. Sebagai contoh Epigallocatechin gallate (EGCG), salah satu flavonoid yang terdapat dalam teh, dapat berikatan dengan reseptor Fas (CD-95 atau APO-1) sehingga dapat menginduksi apoptosis melalui jalur ekstrinsik ${ }^{9}$. Flavonoid yang lain, misalnya resveratrol, menginduksi p38 MAPK dan memediasi aktivasi p53 yang berakibat terhambatnya siklus sel dan mengawali jalur apoptosis. Penelitian lain menyebutkan bahwa efek stimulasi apoptosis dari resveratrol juga diperlihatkan melalui sebuah jalur mitokondria baru yang dikontrol oleh Bcl-2 ${ }^{11}$ Mekanisme antioksidan dalam sel dapat digambarkan pada Gambar 1.

Penelitian lain yang berhubungan dengan antioksidan memiliki potensi sebagai anti kanker adalah kurkumin. Aktivitas antioksidan senyawa kurkumin dapat terjadi karena pembentukan radikal bebas dihambat oleh senyawa kurkumin dengan cara menekan aktivitas sitokrom p450 (isoenzim yang penting untuk bioaktivasi awal pada benzo[a]pyrene) atau adanya spesies oksigen reaktif dideaktivasi secara enzimatik oleh GST (glutathione $S$ - transferase) sehingga dapat menghambat aktivitas mutagenik dari benzo[a]pyrene ${ }^{12}$. Sifat kurkumin dapat menghambat lipid peroksidasi yang terinduksi oleh berbagai agent selular atau zat asing sangat berperan dalam mekanisme aktivitas kurkumin sebagai antiinflamasi, antitumor dan aktivitas farmakologi lainnya ${ }^{12}$.

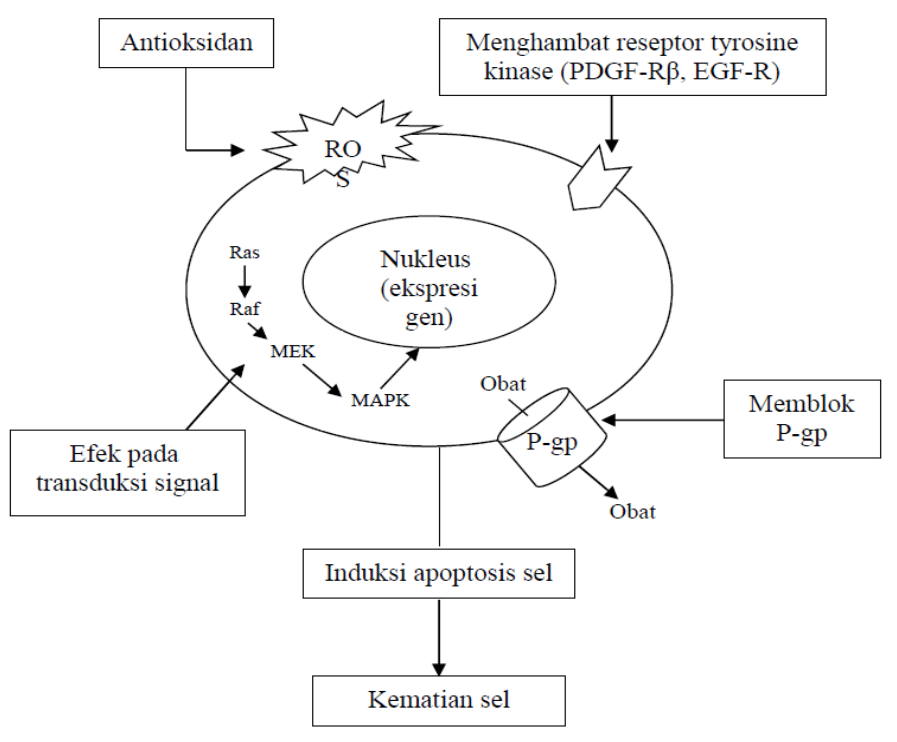

Gambar 1. Mekanisme antioksidan (flavonoid) sebagai antikanker ${ }^{9}$

Dalam produk pangan, antioksidan dapat digunakan untuk mencegah terjadinya proses oksidasi yang dapat menyebabkan kerusakan, seperti ketengikan, perubahan warna, aroma, dan kerusakan fisik lainnya. Antioksidan dapat berbentuk gizi seperti vitamin $\mathrm{E}$ dan $\mathrm{C}$, non-gizi (pigmen karoten, likopen, flavonoid, dan klorofil), dan enzim (glutation peroksidase, koenzim Q10 atau ubiquinon). Antioksidan dapat dibagi menjadi 3 golongan, yaitu antioksidan preventif (enzim superoksidadismutase, katalase, dan glutation peroksidase), antioksidan primer (vitamin A, fenolat, flavonoid,katekin, kuersetin), dan antioksidan komplementer (vitamin $\mathrm{C}, \beta$-karoten, retinoid) $^{13}$. 
Fungsi paling efektif dari antioksidan dalam menghambat terjadinya oksidasi adalah dengan menghentikan reaksi berantai dari radikal-radikal bebas. Pada tubuh manusia menggunakan sistem perlawanan dengan antioksidan untuk menetralkan adanya oksigen yang reaktif atau radikal bebas. Penggunaan antioksidan ini dalam sistem penetralan dapat dalam bentuk enzim ataupun non enzimatis. Beberapa antioksidan berupa enzim ditemukan untuk melindungi dari radikal bebas seperti superoxide dismutases, catalases, and glutathione peroxidases. Sedangkan antioksidan yang berupa non enzimatis berupa molekul kecil yang terdisdribusi secara luas dalam sistem biologis dan dapat melawan radikal bebas ${ }^{13}$.

Zat antioksidan telah dipercaya dapat membantu menangkal beberapa penyakit seperti kanker, kista, hipertensi, penyakit paru-paru, penyakit tulang, hepatitis, diabetes, asam urat, penyakit kulit, mencegah alergi, menambah kesuburan, dan meningkatkan kekebalan tubuh. Antioksidan dapat mencegah dan mengobati penyakit kanker. Radikal bebas yang ada di dalam tubuh akan merusak asam lemak tak jenuh ganda pada membrane sel sehingga mengakibatkan kerapuhan dinding sel, sistem genetika kacau dan timbul pembentukan sel kanker ${ }^{9}$. Radikal bebas menyerang inti sel pada organ tertentu kemudian sel akan membelah terus tanpa terkendali. Sel kanker dapat merambat dan meluas pada sel lainnya. Antioksidan akan menghalangi radikal bebas pada saat merusak inti sel dengan cara memberikan atom hidrogen dari antioksidan kepada radikal bebas sehingga radikal bebas menjadi stabil. Pada penyakit kista, radikal bebas menyerang inti sel dari organ yang diserang, sehingga melakukan pembelahan diri dengan tidak terkendali dan mengalami mutasi. Antioksidan bekerja dengan cara memberikan atom hidrogen kepada radikal bebas agar tidak merusak inti sel dan radikal bebas menjadi stabil. ${ }^{9}$

Zat antioksidan dapat mencegah kerusakan pembuluh darah sejak dini apabila dikonsumsi secara rutin. Antioksidan akan menangkap radikal bebas yang berada dalam pembuluh darah menuju jantung sehingga kerusakan pembuluh darah jantung tidak terjadi ${ }^{13}$. Zat antioksidan dapat mencegah dan memperbaiki kerusakan pada saluran pernapasan serta daerah paru-paru. Radikal bebas yang berasal dari rokok dan zat polutan akan ditangkap oleh antioksidan sehingga memperbaiki kesehatan saluran paru-paru. Pada mata, antioksidan akan menangkap radikal bebas yang masuk ke mata sebelum radikal tersebut mengoksidasi molekul lipid dan protein pada lensa dengan cara mengikat radikal bebas. Sehingga kerusakan mata dapat dicegah. Zat antioksidan akan membantu menangkap radikal bebas yang akan mengoksidasi sel tulang sehingga dapat mencegah kerusakan tulang. Untuk hepatitis, antioksidan akan membantu dengan menangkap radikal bebas, mencegah mutasi gen, dan memperbaiki sel hati yang $\operatorname{rusak}^{13}$. Berdasarkan hal tersebut, maka ekstrak kulit salak memiliki potensi besar sebagai produk hasil olahan biji salak yang bernilai ekonomi karena mengandung antioksidan yang bermanfaat bagi kesehatan, khususnya sebagai antikanker.

Potensi lain yang dapat juga dikembangkan dari produk ekstrak kulit salak adalah sebagai antidiabetes. Beberapa senyawa aktif yang biasanya dipercaya 
sebagai obat pencegahan dan penanganan terapi diabetes yaitu mengandung mengandung senyawa aktif seperti alkaloid, flavonoid, saponin, steroid dan triterpenoid, fenolik hidrokuinon, tannin, dan asam sinamat.

Kulit salak mengandung unsur aktif. Keseluruhan unsur aktif tersebut bekerja secara bersamaan pada tubuh pasien untuk menyembuhkan penyakit pasien. Diantara unsur aktif yang terkandung di dalam kulit salak yang berkhasiat untuk menyembuhkan penyakit diabetes adalah:

1. Ferulic Acid dan Proline; senyawa yang mendorong terbetuknya kolagen dan elastin (dua unsur penting untuk memulihkan jaringan).

2. Cinnamic acid derivatives; senyawa yang mendorong regenerasi sel epitel. Zat-zat di atas berperan penting dalam proses perbaikan pancreas pada penderita diabetes tipe $\mathrm{I}^{14}$.

3. Arginin; senyawa yang menstimulir pembelahan sel dan memperkuat biosintesa protein. Zat Bee Health Products \& Bee Health Propolis ini sangat bermanfaat untuk normalisasi sel-sel tubuh agar responsive pada insulin, zat ini sangat dibutuhkan oleh penderita diabetes tipe II.

4. Pterostilbene; senyawa ini merupakan zat anti diabetes dan berperan langsung dalam menurunkan kadar gula darah ${ }^{3}$.

\section{SIMPULAN DAN SARAN}

\section{Simpulan}

Berdasarkan hasil penelitian dapat disimpulkan sebagai berikut.

Kandungan karbohidrat, protein, kapasitas antioksidan dan IC50 berturut-turut untuk masing-masing komposisi yaitu komposisi 1\% :-0,04\%; 0,21\%; 20,70 ppm, 426,58 ppm; (2) komposisi 5\% : 0,82\%; 0,20\%; 73,40 ppm; 151,41 ppm; (3) komposisi 10\%: 0,93\%; 0,20\%; 110,29 ppm; 87,11 ppm; (4) kulit salak : 28,14\%; 44,90\%; 215,10 ppm; 56,10 ppm, dan non komposisi :1,00\%; 0,00\%; 25,73 ppm; 92,18 ppm.

Kandungan gizi yang paling berpotensi pada ekstrak kulit salak yang akan menjadi produk teh kulit salak adalah kandungan antioksidannya. Kandungan antioksidannya memiliki tingkat kekuatan aktif pada kulit salak dan komposisi campuran $10 \%$.

\section{Saran}

Saran yang dapat disampaikan dalam penelitian ini adalah sebagai berikut.

Perlu dilakukan uji lebih lanjut mengenai jenis antioksidan yang terlarut dalam air pada ekstrak kulit salak.Perlu dilakukan pengujian mengenai potensi ekstrak kulit salak untuk kesehatan seperti antikanker dan antidiabetes. 


\section{DAFTAR PUSTAKA}

1. Afrianti L.H., E. Y. Sukandar, S. Ibrahim, I K. Adnyana. Senyawa Asam 2-Metilester - $1-H$ - Pirol - 4Karboksilat dalam Ekstrak Etil Asetat Buah Salak Varietas Bongkok sebagai Antioksidan dan Antihyperuricmia. Jurnal Teknologi dan Industri Pangan, Vol. XXI No.1 Th. 2010

2. Ariviani S., N. H. R. Parnanto. Kapasitas Antioksidan Buah Salak (Salacca Edulis Reinw) Kultivar Pondoh, Nglumut dan Bali serta Korelasinya dengan Kadar Fenolik Total dan Vitamin C. AGRITECH, Vol. 33, No. 3, Agustus 2013

3. Sahputra, F.M. Potensi Ekstrak Kulit dan Daging Buah Salak Sebagai Antidiabetes. Bogor: Program Studi Biokimia Fakultas MIPA, 2008.

4. Fitrianingsih S.P., F. Lestari, S. Aminah.. Uji Efek Antioksidan Ekstrak Etanol Kulit Buah Salak [Salacca Zalacca (Gaertner) Voss] Dengan Metode Peredaman DPPH. Prosiding SNaPP2014 Sains, Teknologi, dan Kesehatan ISSN 2089-3582, 2014.

5. Sudarmadji, S., B. Haryono, Suhardi. Prosedur Analisa untuk Bahan Makanan dan Minuman. Yogyakarta: Liberty, 1997.

6. Suprapto B, Biological Antioxidant : What are They ?. Kumpulan Makalah Lengkap PIT VII Endokrinologi, Surakarta : UNS Press, hal : 25-29, 2006.

7. Azzamy. 4 Jenis Teh Terpopuler dan Manfaatnya. Diakses pada http://mitalom.com/4-jenis-tehterpopuler-dan-manfaatnya/, diakses tanggal 7 Oktober 2015, 2015
8. Boskou Dimitrios. Sources Of Natural Phenolic Antioxidants. Trends in Food Science \& Technology 17 (2006) 505512, 2006.

9. Demeule $\mathrm{M}$, et al. Green tea catechins as novel antitumor and antiangiogenic compounds. [Online]. Curr. Med. Chem. - Anti Cancer Agents; 2:441-63. Available from: EBSCO Publising. 2002.

10. Hadi SM, Asad SF, Singh S, Ahmad A. Putative mechanism for anticancer and apoptosis-inducing properties of plantderived polyphenolic compounds. [Online]. IUBMB Life 2000;50:167-71. Available from: EBSCO Publising. 2000.

11. Tinhover I, et al.Resveratrol, a tumorsuppressive compound from grapes, induces apoptosis via anovel mitochondrial pathway controlled by Bcl-2. FASEB $\mathrm{J}$ [serial online] 200115:1613-15. Available from: URL:http://www.fasebj.org/

12. Majeed M, V. Badmaev, U. Shirakumar Rajendran R 1995. Curcuminoids Antioxidant Phytonutrients. Pis Cathway : 3-24., NJ.: Nutrition Science Publisher Inc.

13. Irmawati. Keajaiban Antioksidan. Jakarta Timur: Padi, 2014.

14. Hartanti, S. Inhibitory potential of some synthetic cinnamic acid derivatives towars tyrosinase enzyme. Indo.j. Chem. 9: 158168.2009. 